\title{
PENGGUNAAN METODE HOUSE OF RISK UNTUK ANALISIS FAKTOR KETERLAMBATAN DAN PENYUSUNAN STRATEGI PENANGANAN: STUDI KASUS PEMBANGUNAN MALL
}

\author{
Ramdhan Yundra Saputra, Imam Baihaqi \\ Magister Manajemen Teknologi, Institut Teknologi Sepuluh November Surabaya \\ e-mail: ramdhan.sipil@yahoo.com, ibaihaqi@mb.its.ac.id
}

\begin{abstract}
In the work plan there are often operational problems that hinder the completion of a project such as lack of resources, improper resource allocation, delays in project implementation and other issues beyond the schedule in the work plan. The same happened to the mall development project experiencing operational problems. Project delays may come from service providers as well as from users of services or other parties. Therefore this thesis aims to analyze the factors causing the delay in completion of the mall development project. The method used in analyzing the problem in this project is house of delay which serves to analyze data of cause of delay. From the result of 5 delay events, 13 delay agents are then searched aggregate delay potential (ADP) value to determine 3 main problems causing delays in this project. Based on the analysis using the HOR method, found that the three main causes of the delay of mall development is the image changes, lack of coordination by the owner, and the addition of the scope of work. These 3 problems can be minimized by making good communication and coordination with the owner, creating procedures for making and changing pictures, creating a comprehensive check list.
\end{abstract}

Keywords: construction delay factors, house of delay, delay management

\section{PENDAHULUAN}

Dalam proyek pembangunan mall sering terjadi keterlambatan yang disebabkan oleh adanya disputes. Disputes tersebut berasal dari beberapa faktor antar stakeholder, yang mana setiap stakeholder mempunyai permasalahan yang berbeda-beda dan hal tersebut memerlukan waktu yang cukup lama untuk mengidentifikasi faktor penyebabnya dan menemukan solusi yang tepat.

Selain itu terdapat pula beberapa faktor yang diduga memengaruhi keterlambatan proyek di antaranya berasal dari penyedia jasa, pengguna jasa maupun pihak lain yang dapat berdampak terhadap penambahan waktu dan biaya di luar rencana. Apabila faktor keterlambatan berasal dari kontraktor (penyedia jasa) maka kontraktor dapat dikenakan denda, begitu sebaliknya jika keterlambatan berasal dari pengguna jasa, maka pengguna jasa akan membayar kerugian yang ditanggung oleh penyedia jasa, yang jumlahnya ditetapkan dalam kontrak sesuai perundangundangan yang berlaku.

Dalam perencanaan kerja sering kali timbul masalah-masalah operasional yang menghambat aktivitas penyelesaian suatu proyek seperti kurangnya sumber daya, alokasi sumber daya yang tidak tepat, keterlambatan pelaksanaan proyek dan masalah lainnya di luar jadwal dalam rencana kerja (Nicholas, 1990). Sering kali dalam pelaksanaan proyek terjadi keterlambatan yang tidak diinginkan dan tidak diketahui sebelumnya. Keterlambatan tersebut sangat merugikan pihakpihak terkait, seperti kontraktor dan owner.

Assaf et al. (1995) menyebutkan bahwa penyebab keterlambatan antara lain dapat dilihat dari sisi material, tenaga kerja, peralatan, biaya, 
perubahan-perubahan desain, hubungan dengan instansi terkait, penjadwalan dan pengendalian, lambatnya prosedur pengawasan dan pengujian yang dipakai dalam proyek, lingkungan, masalah kontrak, dan tidak adanya konsultan manajer profesional. Dengan menggunakan relative importance index, Haseeb (2011) menemukan bahwa terdapat lima faktor utama penyebab terjadinya keterlambatan proyek pada industri konstruksi di Pakistan yaitu time overrun, cost overrun, abandonment, negotiations and court cases, dan disputes.

Terlepas dari semua perencanaan yang ada, proses pembangunan mall sering kali terganggu oleh dispute yang muncul selama proses pembangunan berlangsung sehingga berpengaruh terhadap kinerja waktu dalam penyelesaian proyek. Hal tersebut merupakan permasalahan yang harus dicari solusinya. Selain itu, diperlukan langkah analisis keterlambatan serta bagaimana memitigasi faktor keterlambatan tersebut. Tujuan yang ingin dicapai dari penelitian ini yaitu mengidentifikasi faktor-faktor keterlambatan yang mungkin timbul dalam proses pembangunan mall, dan melakukan analisis terhadap keterlambatan yang berpeluang terjadi selama pelaksanaan proyek, serta menentukan langkah mitigasi yang efektif untuk mengurangi kemungkinan terjadi keterlambatan.

Maka dari itu, pada paper ini akan diteliti faktor-faktor penyebab keterlambatan proyek dan bagaimana memitigasi keterlambatan tersebut pada proyek pembangunan mall. Untuk mengidentifikasi penyebab keterlambatan dan analisis mitigasinya, paper ini akan mencoba mengadopsi metode house of risk yang dikembangkan oleh Pujawan (2009) untuk mencari penyebab dan solusi dari keterlambatan tersebut. Metode house of riks adalah metode sistematis untuk mengidentifikasi risiko dan penyebab ri- siko serta bagaimana mengurangi atau mengeliminasi penyebab risiko ke dalam suatu program pencegahan dan mitigasi keterlambatan. Dalam paper ini, metode ini diaplikasikan dengan menganalogikan risiko sebagai kejadian keterlambatan dengan tetap menggunakan tahap-tahap yang ada pada metode house of risk yang nantinya akan menjadi house of delay. Metode ini diharapkan dapat menghasilkan suatu strategi prioritisasi pemeliharaan yang proaktif dengan memfokuskan pada identifikasi keterlambatan proyek, penyebab keterlambatan, menentukan prioritas dan strategi penanganan dalam penyelesaian proyek pembangunan Mall. Dengan mengurangi faktor penyebab keterlambatan diharapkan dampaknya dapat dikurangi atau dicegah.

\section{METODE}

Paper ini disusun sebagai berikut mengadopsi tahap-tahap yang ada pada house of risk (HOR) untuk mencari faktor keterlambatan dan penanganan yang pada paper ini menjadi house of delay (HOD).

\section{HOD (House of Delay)}

Metode house of delay adalah metode untuk mengelola keterlambatan secara proaktif yang berfokus pada tindakan pencegahan, di mana agen keterlambatan yang teridentifikasi sebagai penyebab kejadian keterlambatan dapat dikelola dengan langkah proaktif yang efektif untuk dapat mengurangi kemungkinan terjadinya agen keterlambatan sehingga kejadian keterlambatan dapat dikurangi atau dicegah. Langkah proaktif tersebut dilakukan sesuai dengan urutan besarnya dampak yang mungkin ditimbulkan.

Pendekatan house of delay (HOD) ini dibagi menjadi dua fase sebagai berikut. 
Ramdhan Yundra Saputra \& Imam Baihaqi, Penggunaan Metode House of Risk untuk Analisis Faktor Keterlambatan dan Penyusutan Strategi Penanganan: Studi Kasus Pembangunan Mall

Tabel 1 Model HOD 1

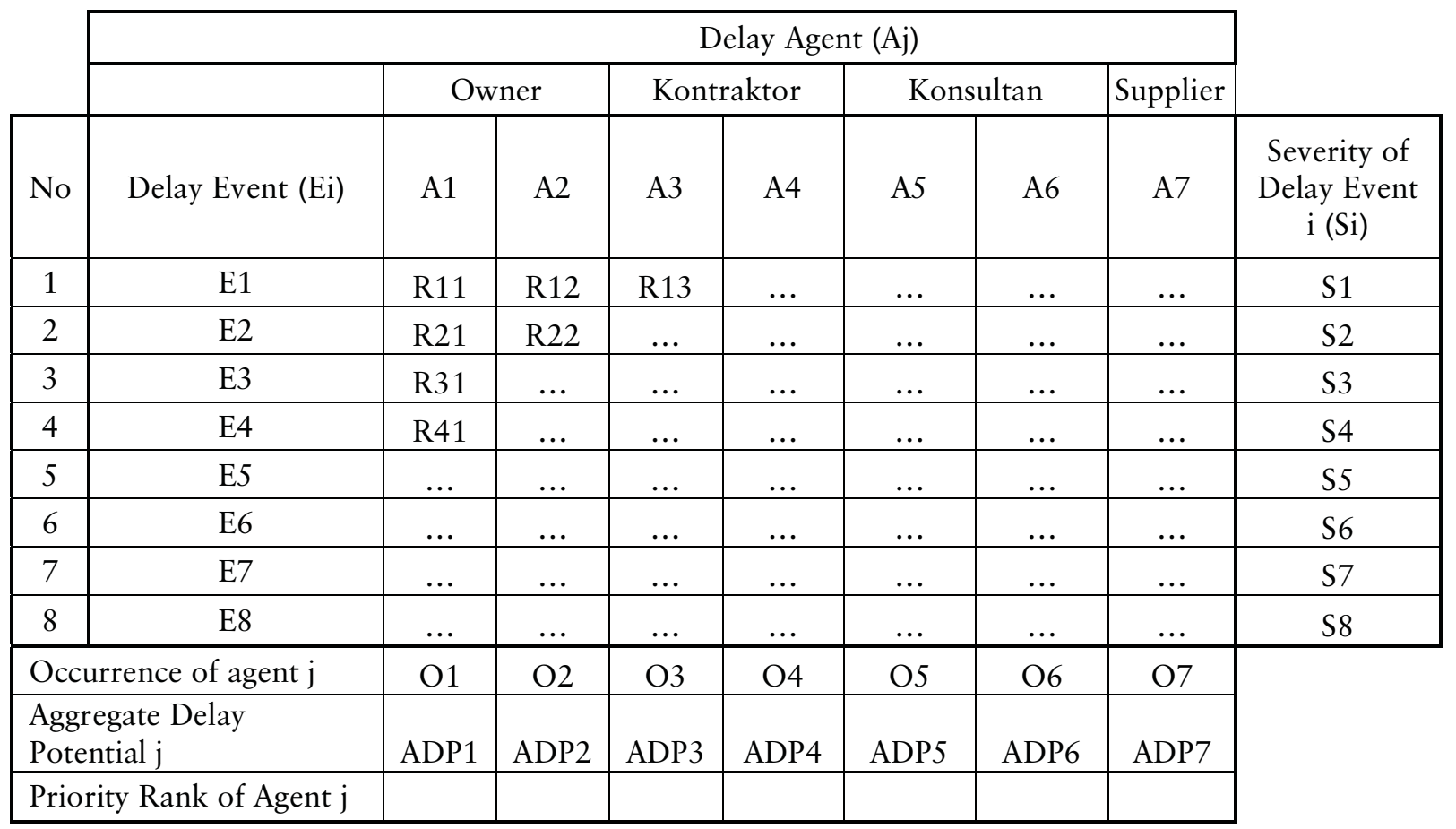

\section{HOD 1}

HOD1 digunakan untuk menentukan atau mengidentifikasi agen keterlambatan untuk diberikan prioritas pencegahan. Mengidentifikasi urutan agen keterlambatan dengan menggunakan HOD1 seperti pada Tabel 1 dan dapat dilakukan dengan langkah seperti berikut.

a. Identifikasi delay events/kejadian keterlambatan $\left(\mathrm{E}_{\mathrm{i}}\right)$ yang terjadi dalam setiap bisnis proses.

b. Identifikasi besarnya dampak keparahan/severity $\left(\mathrm{S}_{\mathrm{i}}\right)$ jika delay event tersebut terjadi. Gunakan skala 1 hingga 5 untuk menilai dampak tersebut, yang mana 5 menggambarkan dampak keparahan sangat sulit.

c. Identifikasi delay agents dan lakukan penilaian terhadap probabilitas $\left(\mathrm{O}_{\mathrm{i})}\right.$ terjadinya (occurrence/A) setiap delay agent tersebut. Gunakan skala 1 hingga 6, yang mana 1 berarti hampir tidak pernah terjadi dan 6 adalah hampir pasti terjadi. d. Tentukan matriks korelasi antar-masingmasing agen keterlambatan $\left(\mathrm{R}_{\mathrm{ij})}\right.$ dan kejadian setiap keterlambatan, gunakan skala $0,1,3$, 9, di mana 0 mewakili tidak ada korelasi, 1 menyatakan korelasi rendah, 3 berarti sedang, dan 9 korelasi tinggi.

e. Hitung nilai aggregate delay potential agen J $\left(\mathrm{ADP}_{\mathrm{j}}\right)$. Rumus perhitungan seperti berikut:

$$
\mathrm{ADP}_{\mathrm{j}}=\mathrm{O}_{\mathrm{j}} \sum_{\mathrm{i}} \mathrm{S}_{\mathrm{i}} \mathrm{R}_{\mathrm{ij}}
$$

f. Meranking agen keterlambatan sesuai dengan nilai ADP, diurutkan mulai dengan nilai terbesar ke nilai yang terendah.

\section{HOD 2}

HOD2 adalah prioritas solusi penanganan yang efektif sesuai dengan anggaran dan resource yang ada. Model dari HOD2 tersebut dapat dilihat di Tabel 2 dan langkah dari HOD2 adalah sebagai berikut. 
a. Pilih beberapa agen keterlambatan yang mempunyai ranking prioritas yang paling tinggi (bigh-priority rank) yang dihasilkan dari nilai perhitungan ADP pada langkah di HOD1.

b. Identifikasi tindakan pencegahan $\left(P A_{k)}\right.$ yang dianggap efektif dan relevan dengan agen keterlambatan tersebut. Satu agen keterlambatan bisa ditangani oleh lebih dari satu tindakan pencegahan dan satu tindakan pencegahan bisa secara bersamaan mengurangi probabilitas terjadinya lebih dari satu agen keterlambatan.

c. Tentukan hubungan antara setiap tindakan pencegahan dan setiap agen keterlambatan $\left(E_{j k)}\right.$ dengan menggunakan skala $0,1,3,9$, di mana 0 mewakili tidak ada korelasi, 1 menyatakan korelasi rendah, 3 berarti sedang, dan 9 korelasi tinggi antara aksi $k$ dan agen $j$.

d. Hitung nilai total efektivitas setiap tindakan. Nilai ini dapat menyatakan bagaimana tindakan yang diambil tersebut benar-benar dapat mengatasi probabilitas dari agen keterlam- batan. Rumus dari total efektivitas adalah sebagai berikut:

$$
\mathrm{TE}_{\mathrm{k}}=\sum_{\mathrm{j}} \mathrm{ADP}_{\mathrm{j}} \mathrm{E}_{\mathrm{jk}}
$$

e. Menilai tingkat kesulitan dalam melakukan setiap tindakan $\left(\boldsymbol{D}_{k)}\right.$. Tingkat kesulitan tindakan pencegahan ini harus dapat mengakomodasi dan mencerminkan anggaran dan sumber daya lainnya yang dibutuhkan dalam melakukan tindakan pencegahan tersebut.

f. Hitung total efektivitas rasio tingkat kesulitan $\left(E T D_{k}\right)$ dengan rumus sebagai berikut:

$$
\mathrm{ETD}_{\mathrm{k}}=T E k / D k
$$

g. Berikan ranking prioritas untuk setiap tindakan pencegahan $\left(\boldsymbol{R}_{k}\right)$ Prioritas untuk setiap tindakan pencegahan dinyatakan sesuai dengan nilai dari efektivitas rasio tingkat kesulitan $\left(E T D_{k}\right)$ di mana urutan 1 diberikan pada tindakan pencegahan dengan nilai total efektivitas dari tingkat kesulitan paling tinggi. Tindakan pencegahan tertinggi menggambarkan tindakan pencegahan yang paling efektif dari segi biaya.

Tabel 2 Model HOD 2

\begin{tabular}{|c|c|c|c|c|c|c||}
\cline { 2 - 7 } \multicolumn{1}{c|}{} & \multicolumn{5}{c|}{ Preventive Action (PAK) } & \\
\hline To be treated delay agen (Aj) & PA1 & PA2 & PA3 & PA4 & PA5 & $\begin{array}{c}\text { Aggregate } \\
\text { Delay } \\
\text { Potensial } \\
\text { ADPj) }\end{array}$ \\
\hline A1 & & & & & & ADP1 \\
\hline A2 & E11 & E12 & E13 & $\ldots$ & $\ldots$ & ADP2 \\
\hline A4 & E21 & E22 & $\ldots$ & $\ldots$ & $\ldots$ & ADP3 \\
\hline A5 & E31 & $\ldots$ & $\ldots$ & $\ldots$ & $\ldots$ & ADP4 \\
\hline Total effectiveness of action k & $\ldots$ & $\ldots$ & $\ldots$ & $\ldots$ & $\ldots$ & ADP5 \\
\hline Degree of difficulty performing action k & $\ldots$ & $\ldots$ & $\ldots$ & $\ldots$ & Ejk & \\
\hline Effectiveness to difficulty ratio & TE1 & TE2 & TE3 & TE4 & TE5 & \\
\hline Rank of priority & ETD1 & ETD2 & ETD3 & ETD4 & ETD5 & \\
\hline
\end{tabular}




\section{HASIL DAN PEMBAHASAN}

\section{Identifikasi Kejadian Keterlambatan}

PT XYZ adalah salah satu perusahaan yang bergerak di bidang property dan real estate yang ada di Surabaya. Sejak didirikan mulai tahun 1990 sampai saat ini, perusahaan ini sudah berpartisipasi dalam memproduksi unit perumahan beserta superblock area yang berada pada tiga lokasi strategis di Surabaya yaitu Surabaya Timur, Surabaya Tengah, dan Surabaya Barat.

Di Surabaya barat, PT XYZ memiliki superblock terbesar yang terdiri dari hotel bintang lima, kondominium mewah, dan twin tower apartemen yang bernama Mall, yang juga merupakan pusat perbelanjaan terbesar, termegah, dan terluas di Indonesia dengan luas $180.000 \mathrm{~m}^{2}$ leasable area. Mall tersebut nantinya akan membantu penduduk real estate untuk memenuhi kebutuhan rumah tangga.

Proyek adalah kegiatan yang melibatkan sumber daya berupa tenaga kerja, peralatan konstruksi, material, uang, dan metode. Pada proyek pembangunan mall banyak sekali didapat dispute yang terjadi pada masa penyelesaian proyek, Sasaran proyek adalah diselesaikannya konstruksi fisik bangunan dengan tepat biaya, tepat waktu, dan tepat mutu. Pada proses tersebut dapat terjadi keterlambatan yang tidak diharapkan. Jika keterlambatan-keterlambatan tersebut terjadi maka proyek tidak dapat mewujudkan sasarannya yaitu tepat biaya atau tepat waktu atau tepat. Keterlambatan yang potensial adalah keterlambatan yang memiliki frekuensi terjadi yang tinggi dan memiliki pengaruh besar bagi pencapaian sasaran proyek.

Bagian-bagian pada operasional proyek yang memiliki keterlambatan tinggi menunjukkan bahwa bagian tersebut kurang ditangani dengan baik karena kurangnya kapabilitas sumber daya, baik dari manajer proyeknya maupun organisasi pro- yek. Data yang digunakan dalam penelitian ini diperoleh pada wawancara dengan stakeholder. Terdapat event keterlambatan proyek mall yang diidentifikasi dalam wawancara tersebut, 5 event keterlambatan ditemukan di lapangan serta dalam wawancara dengan stakeholder yang berhubungan dengan proyek pembangunan mall dan divalidasi oleh owner dan konsultan, hasil survei responden dapat dilihat pada Tabel 3.

Tabel 3 Identifikasi Keterlambatan dan Hasil Penilaian Dampak Keterlambatan

\begin{tabular}{|c|l|c|}
\hline Kode & \multicolumn{1}{|c|}{ Delay Event } & Severity \\
\hline E1 & $\begin{array}{l}\text { Keterlambatan pembayaran oleh } \\
\text { owner }\end{array}$ & 3 \\
\hline E2 & Keterlambatan material & 2 \\
\hline E3 & $\begin{array}{l}\text { Keterlambatan pekerjaan akibat } \\
\text { kesalahan kontraktor/subkontraktor }\end{array}$ & 4 \\
\hline E4 & $\begin{array}{l}\text { Keterlambatan pekerjaan akibat } \\
\text { kesalahan owner }\end{array}$ & 4 \\
\hline E5 & $\begin{array}{l}\text { Keterlambatan serah-terima } \\
\text { pekerjaan kontraktor }\end{array}$ & 4 \\
\hline
\end{tabular}

Dari 1 diketahui sebanyak 3 kejadian keterlambatan yang mempunyai nilai 4 yang artinya berdampak parah dan sangat berpengaruh pada penyelesaian proyek menurut validasi pada saat wawancara, 1 kejadian keterlambatan dengan nilai 3 ini berarti berdampak sedang karena sebagian kontraktor pada proyek pembangunan mall mempunyai pembiayaan yang cukup dan 1 kejadian keterlambatan dengan nilai 2 yang berdampak di bawah sedang karena pada proyek mall material jarang terjadi keterlambatan. Nilai dampak ini akan digunakan dalam perhitungan aggregate delay potential (ADP), yaitu untuk menentukan agen/penyebab keterlambatan yang paling berpengaruh berdasarkan perhitungan.

\section{Identifikasi Agen/Penyebab Keterlambatan}

Identifikasi penyebab/agen keterlambatan berasal dari wawancara yang dilakukan peneliti 
dengan antar-stakeholder dan data yang ada pada proyek mall. Berawal dari event keterlambatan peneliti menelusuri lewat wawancara dan data apa saja yang menjadi agent keterlambatan, dapat dilihat pada Tabel 4.

Tabel 4 Identifikasi Agen Keterlambatan

\begin{tabular}{|c|c|c|}
\hline No. & Delay Event & Delay Agent \\
\hline \multirow[t]{5}{*}{1} & \multirow{5}{*}{$\begin{array}{l}\text { Keterlambatan pembayaran } \\
\text { ke kontraktor }\end{array}$} & Terjadinya tabrakan lingkup kerja antar-kontraktor \\
\hline & & Berkas kontraktor tidak sesuai \\
\hline & & Adanya penambahan lingkup kerja \\
\hline & & Lama proses Pembayaran pada owner \\
\hline & & Gambar berubah-ubah \\
\hline \multirow[t]{3}{*}{2} & \multirow[t]{3}{*}{ Keterlambatan material } & Material didatangkan dari luar \\
\hline & & Material berbeda harga dasar \\
\hline & & Pembayaran material tertunda \\
\hline \multirow[t]{7}{*}{3} & \multirow{7}{*}{$\begin{array}{l}\text { Keterlambatan pekerjaan } \\
\text { akibat kesalahan } \\
\text { kontraktor/subkontraktor }\end{array}$} & Kurangnya SDM \\
\hline & & Terdapat konflik dan kesalahpahaman \\
\hline & & $\begin{array}{l}\text { Survei awal kontrak pada kontraktor tidak sesuai } \\
\text { dengan yang di kerjakan }\end{array}$ \\
\hline & & Terjadinya tabrakan lingkup kerja antar kontraktor \\
\hline & & Koordinasi dengan owner \\
\hline & & Adanya nego ulang harga baru dan volume \\
\hline & & Berkas kontraktor tidak lengkap \\
\hline \multirow[t]{5}{*}{4} & \multirow{5}{*}{$\begin{array}{l}\text { Keterlambatan pekerjaan } \\
\text { akibat kesalahan owner }\end{array}$} & Permintaan customer berbeda \\
\hline & & Gambar yang berubah-ubah \\
\hline & & Adanya penambahan lingkup kerja \\
\hline & & Proses pembayaran cukup lama \\
\hline & & Adanya nego ulang harga baru dan volume \\
\hline \multirow[t]{11}{*}{5} & \multirow{11}{*}{$\begin{array}{l}\text { Keterlambatan serah terima } \\
\text { pekerjaan kontraktor }\end{array}$} & Gambar yang berubah-ubah \\
\hline & & Kurangnya SDM \\
\hline & & Terdapat konflik dan kesalahpahaman \\
\hline & & $\begin{array}{l}\text { Survei awal kontrak pada kontraktor tidak sesuai } \\
\text { dengan yang di kerjakan }\end{array}$ \\
\hline & & Terjadinya tabrakan lingkup kerja antar kontraktor \\
\hline & & Koordinasi dengan owner \\
\hline & & Adanya nego ulang harga baru dan volume \\
\hline & & Kurang matangnya perencanaan \\
\hline & & Adanya penambahan lingkup kerja \\
\hline & & Proses pembayaran cukup lama \\
\hline & & Adanya nego ulang harga baru dan volume \\
\hline
\end{tabular}


Ramdhan Yundra Saputra \& Imam Baihaqi, Penggunaan Metode House of Risk untuk Analisis Faktor Keterlambatan dan Penyusutan Strategi Penanganan: Studi Kasus Pembangunan Mall

Tabel 5 Penilaian Responden Terhadap Probabilitas Kejadian Agen Keterlambatan

\begin{tabular}{|c|l|c|}
\hline Kode & \multicolumn{1}{|c|}{ Delay Agent } & Occurrence \\
\hline A1 & $\begin{array}{l}\text { Terjadi tabrakan dalam } \\
\text { lingkup kerja kontraktor }\end{array}$ & 4 \\
\hline A2 & $\begin{array}{l}\text { Berkas pembayaran } \\
\text { material yang tidak sesuai }\end{array}$ & 2 \\
\hline A3 & Penambahan lingkup kerja & 4 \\
\hline A4 & $\begin{array}{l}\text { Proses pembayaran oleh } \\
\text { owner }\end{array}$ & 2 \\
\hline A5 & Kurang koordinasi owner & 4 \\
\hline A6 & Perbedaan harga dasar & 3 \\
\hline A7 & $\begin{array}{l}\text { Berkas kontraktor tidak } \\
\text { lengkap dan sesuai }\end{array}$ & 3 \\
\hline A8 & $\begin{array}{l}\text { Kurangnya sumber daya } \\
\text { manusia pada kontraktor }\end{array}$ & 4 \\
\hline A9 & $\begin{array}{l}\text { Sumber material berasal } \\
\text { dari luar negeri }\end{array}$ & $\begin{array}{l}\text { Survey awal kontraktor } \\
\text { tidak sesuai }\end{array}$ \\
\hline A10 & Perbedaan volume material & 3 \\
\hline A11 & Perubahan gambar \\
\hline A12 & $\begin{array}{l}\text { Permintaan customer yang } \\
\text { berbeda-beda }\end{array}$ \\
\hline A13 & 2 \\
\hline
\end{tabular}

Nilai probabilitas ini juga akan digunakan dalam perhitungan aggregate delay potential (ADP), yaitu untuk menentukan agen/penyebab keterlambatan yang paling berpengaruh berdasarkan perhitungan.

\section{Penghitungan Aggregate Delay Potential (HOD1)}

Nilai ADP ini diperoleh dari penjumlahan hasil perkalian tingkat severity dengan tingkat occurrence.

$$
\mathrm{ADP}_{\mathrm{j}}=\mathrm{O}_{\mathrm{j}} \sum_{\mathrm{i}} \mathrm{S}_{\mathrm{i}} \mathrm{R}_{\mathrm{ij}}
$$

Terdapat lima kejadian keterlambatan yang telah diidentifikasi. Agen/penyebab keterlambatan yang telah diidentifikasi pada tahap sebelumnya terdapat 13 . Satu agen keterlambatan dapat memunculkan satu atau lebih kejadian keterlambatan dan sebaliknya, satu kejadian keterlambatan dapat disebabkan oleh satu atau lebih agen keterlambatan. Perhitungan HOD1 dan peringkat agen keterlambatan dari yang paling tinggi bisa dilihat pada Tabel 6 .

Dari hasil HOD1 didapat peringkat di atas dan diambil 3 tertinggi dengan diagram pareto 20:80 untuk nantinya agen keterlambatan tersebut dicari solusi penanganannya pada HOD2. Diagram tersebut dapat dilihat pada Gambar 1.

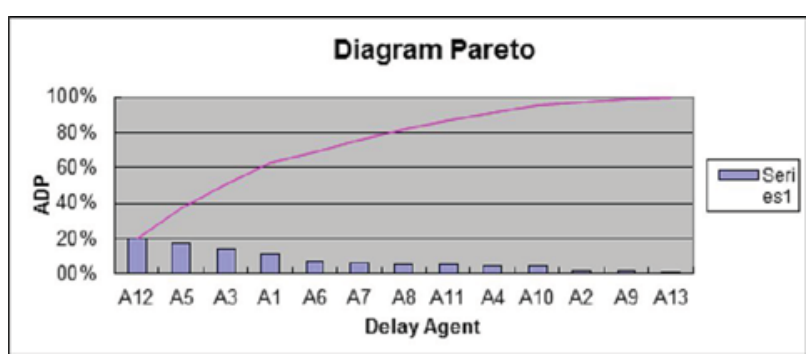

Gambar 1 Diagram Pareto HOD1

Tabel 6 Perhitungan HOD1 dan Peringkat Agen Keterlambatan

\begin{tabular}{|c|c|c|c|c|c|c|c|c|c|c|c|c|c|c|}
\hline & \multicolumn{14}{|c|}{ Delay Agent $(\mathrm{Aj})$} \\
\hline Delay Event (Ei) & A1 & $\mathrm{A} 2$ & A3 & A4 & A5 & A6 & A7 & A8 & A9 & A10 & A11 & A12 & A13 & $\begin{array}{c}\text { Severity of } \\
\text { Delay Event i } \\
\text { (Si) }\end{array}$ \\
\hline E1 & 9 & 0 & 3 & 9 & 3 & 0 & 9 & 0 & 0 & 0 & 0 & 9 & 1 & 3 \\
\hline E2 & 0 & 9 & 1 & 1 & 1 & 1 & 0 & 0 & 9 & 0 & 0 & 1 & 1 & 2 \\
\hline E3 & 9 & 3 & 9 & 0 & 9 & 9 & 9 & 9 & 0 & 9 & 9 & 9 & 1 & 4 \\
\hline E4 & 0 & 0 & 9 & 9 & 9 & 9 & 0 & 0 & 0 & 0 & 3 & 9 & 1 & 4 \\
\hline E5 & 9 & 1 & 9 & 3 & 9 & 1 & 3 & 3 & 3 & 3 & 3 & 9 & 1 & 4 \\
\hline Occurrence of agent $\mathrm{j}$ & 4 & 2 & 4 & 2 & 5 & 3 & 3 & 4 & 2 & 3 & 3 & 5 & 2 & \\
\hline Aggregate Delay Potential j & 396 & 68 & 476 & 154 & 595 & 234 & 225 & 192 & 60 & 144 & 180 & 685 & 34 & \\
\hline Priority Rank of Agent j & 4 & 11 & 3 & 9 & 2 & 5 & 6 & 7 & 12 & 10 & 8 & 1 & 13 & \\
\hline
\end{tabular}




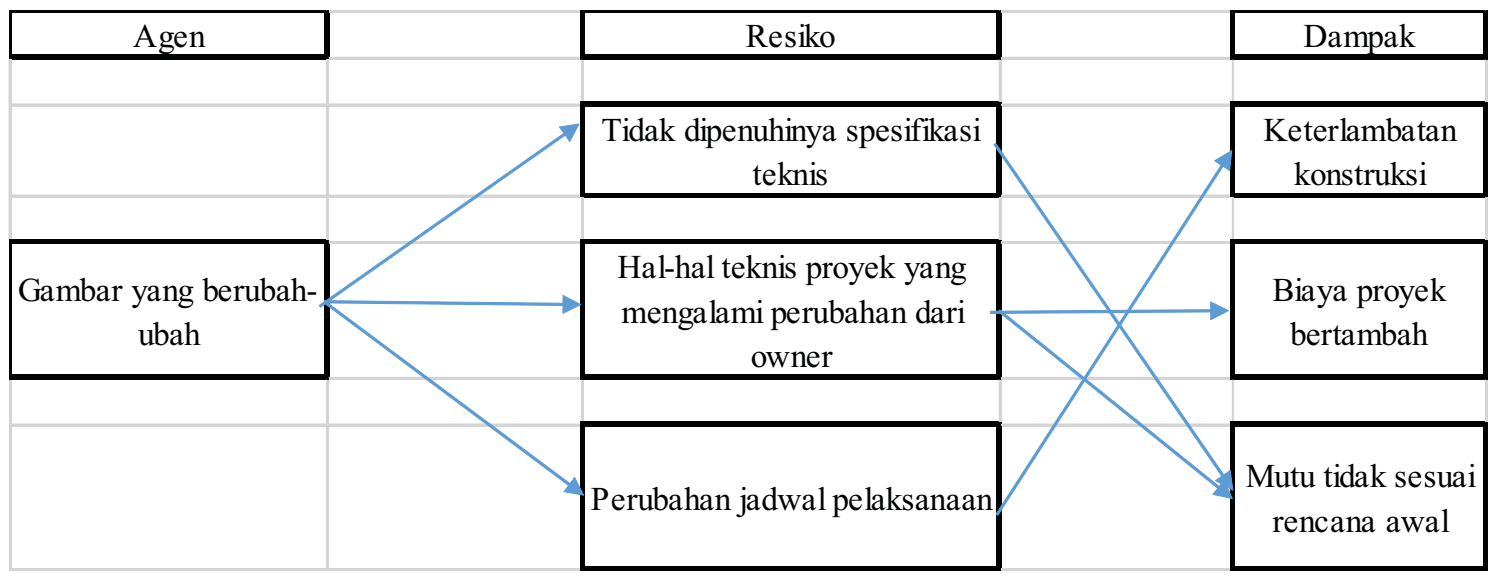

Gambar 2 Akibat dari Gambar Berubah-Ubah

Terlihat dari diagram pareto bahwa masalah utama keterlambatan proyek pembangunan mall adalah terjadi perubahan gambar sehingga menyebabkan banyak terjadinya keterlambatan pekerjaan pada kontraktor. Hal tersebut dikuatkan dengan lampiran data perubahan gambar.

Berdasarkan Gambar Diagram Pareto, 3 peringkat agen keterlambatan teratas adalah sebagai berikut.

1. Gambar yang berubah-ubah (A12), dengan nilai ARP sebesar 685. Jika selalu terjadi perubahan terhadap gambar keterlambatan yang mungkin terjadi adalah sebagai berikut (Gambar 2).

a. Perubahan gambar dapat menyebabkan tidak terpenuhinya spesifikasi teknis yang sesuai dengan gambar terkini.

b. Hal-hal teknis mengenai proyek dapat berubah seiring dengan adanya perubahan gambar.

c. Akibat terjadinya perubahan gambar yang berulang-ulang maka dapat terjadi perubahan jadwal pelaksanaan.

2. Koordinasi dengan owner yang kurang baik (A5), nilai ADP 595. Keterlambatan yang mungkin terjadi jika koordinasi dengan owner kurang baik adalah sebagai berikut (Gambar 3). a. Kondisi keuangan proyek yang buruk, dampak yang akan ditimbulkannya adalah keterlambatan konstruksi, biaya proyek bertambah.

b. Masalah pada koordinasi pelaksanaan, akan berdampak pada keterlambatan konstruksi, mutu pekerjaan tidak sesuai dengan yang direncanakan.

c. Kondisi owner yang kurang mendukung, karena kurang koordinasi, maka akan terjadi kesalahpahaman informasi mengenai spesifikasi pekerjaan, sehingga mutu hasil pekerjaan tidak sesuai dan keterlambatan pelaksanaan konstruksi.

3. Tambahan lingkup kerja (A3), dengan nilai ADP 476. Keterlambatan yang mungkin terjadi jika terjadi penambahan lingkup kerja adalah sebagai berikut (Gambar 4).

a. Tambahan lingkup kerja akan berakibat pada terganggunya jadwal pelaksanaan pekerjaan.

b. Selain itu penambahan lingkup kerja juga akan berdampak pada masalah teknologi atau metode konstruksi, karena pekerjaan tersebut tidak ada dalam perencanaan.

c. Penambahan lingkup kerja juga dapat menyebabkan perubahan jadwal pelaksanaan pekerjaan yang sudah ada sebelumnya. 
Ramdhan Yundra Saputra \& Imam Baihaqi, Penggunaan Metode House of Risk untuk Analisis Faktor Keterlambatan dan Penyusutan Strategi Penanganan: Studi Kasus Pembangunan Mall

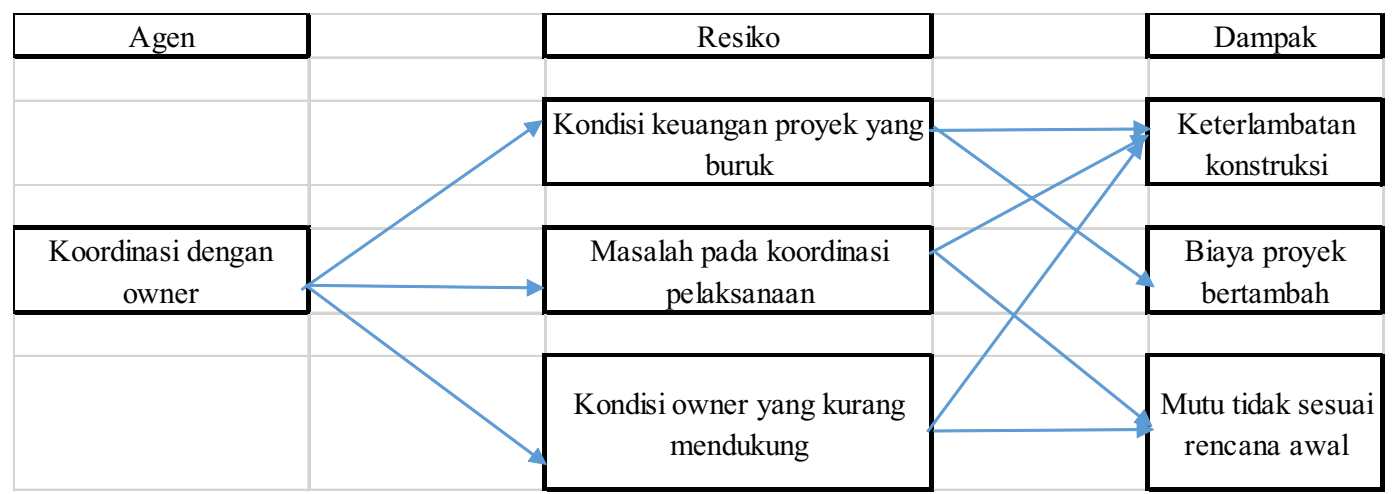

Gambar 3 Akibat dari Koordinasi dengan Owner

\section{Aksi Mitigasi Untuk Penanganan Keterlambatan}

Agen keterlambatan ini kemudian akan dimasukkan ke dalam model HOD fase 2 untuk perancangan aksi mitigasi. Aksi mitigasi yang dimaksud adalah tindakan (action) untuk mengurangi dampak dari suatu agen keterlambatan sebelum keterlambatan itu terjadi. Alternatif aksi mitigasi diperoleh dari brainstorming dengan owner dan kontraktor yang mengalami masalah tersebut. Fokus perancangan aksi mitigasi ini berdasarkan dari agen keterlambatan terpilih (3). Pemetaan aksi mitigasi ini dilakukan dengan tujuan untuk melihat pengaruh aksi mitigasi terhadap agen keterlambatan. Dengan cara melakukan pemetaan opsi aksi mitigasi dengan agen keterlambatan terpilih. Adapun alternatif aksi mitigasi yang dapat dilakukan seperti pada Tabel 7.
Tabel 7 Alternatif Aksi Mitigasi

\begin{tabular}{|c|c|}
\hline $\begin{array}{c}\text { Agen } \\
\text { Keterlambatan }\end{array}$ & Aksi Mitigasi \\
\hline \multirow{2}{*}{$\begin{array}{l}\text { Gambar berubah- } \\
\text { ubah }\end{array}$} & $\begin{array}{l}\text { Membuat prosedur pembuatan } \\
\text { dan perubahan gambar }\end{array}$ \\
\hline & Membuat jadwal yang realistis \\
\hline \multirow{2}{*}{$\begin{array}{l}\text { Kordinasi dengan } \\
\text { owner }\end{array}$} & $\begin{array}{l}\text { Melakukan komunikasi dan } \\
\text { koordinasi yang baik dengan } \\
\text { owner }\end{array}$ \\
\hline & $\begin{array}{l}\text { Melakukan pengawasan terhadap } \\
\text { penjadwalan }\end{array}$ \\
\hline \multirow{2}{*}{$\begin{array}{l}\text { Adanya } \\
\text { penambahan } \\
\text { lingkup kerja }\end{array}$} & $\begin{array}{l}\text { Membuat check list yang } \\
\text { komprehensif }\end{array}$ \\
\hline & $\begin{array}{l}\text { Pemenuhan persyaratan } \\
\text { pembayaran }\end{array}$ \\
\hline
\end{tabular}

Proses perancangan strategi dilakukan menggunakan matriks House of Delay (HOR) fase kedua untuk menyusun aksi-aksi mitigasi dalam menangani keterlambatan yang berpotensi timbul. Penilaian aksi mitigasi dilakukan berda-

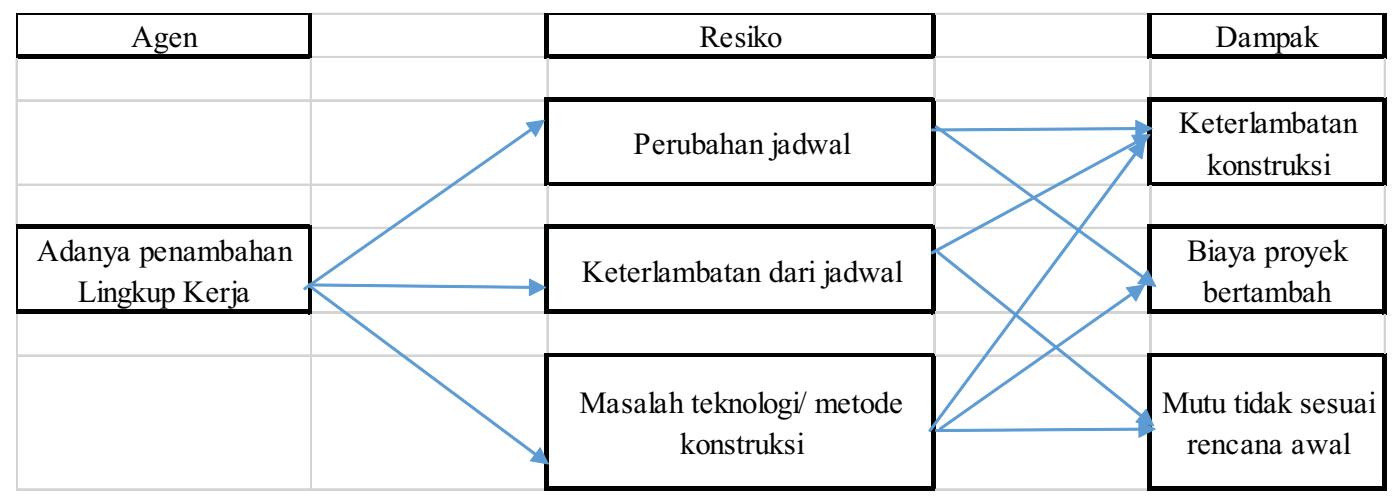

Gambar 4 Akibat dari Adanya Penambahan Lingkup Kerja 
sarkan tingkat kesulitan dalam melakukan masing-masing aksi mitigasi tersebut. Penilaian tersebut didapat dari hasil wawancara dengan owner. Penilaian tersebut dapat dilihat pada Tabel 8.

Tabel 8 Aksi Mitigasi

\begin{tabular}{|c|l|c|}
\hline Kode & \multicolumn{1}{|c|}{ Aksi Mitigasi } & $\begin{array}{c}\text { Tingkat } \\
\text { Kesulitan }\end{array}$ \\
\hline PA1 & Membuat jadwal yang realistis & 3 \\
\hline PA2 & $\begin{array}{l}\text { Membuat check list yang } \\
\text { komprehensif }\end{array}$ & 4 \\
\hline PA3 & $\begin{array}{l}\text { Melakukan komunikasi dan } \\
\text { koordinasi yang baik dengan } \\
\text { owner }\end{array}$ & 4 \\
\hline PA4 & $\begin{array}{l}\text { Pemenuhan persyaratan } \\
\text { pembayaran }\end{array}$ & 3 \\
\hline PA5 & $\begin{array}{l}\text { Membuat prosedur pembuatan } \\
\text { dan perubahan gambar }\end{array}$ & 3 \\
\hline PA6 & $\begin{array}{l}\text { Melakukan pengawasan } \\
\text { terhadap penjadwalan }\end{array}$ \\
\hline
\end{tabular}

\section{Perhitungan Rasio Total Efektivitas dengan Tingkat Kesulitan (HOD2)}

Pada HOR fase kedua akan didapatkan rasio dari efektivitas aksi mitigasi yang sudah ditentukan dengan rumus:

$$
T E_{k}={ }_{j} A D P E_{j k}
$$

Setelah itu didapatkan hasil efektif dengan kesulitan menggunakan rumus seperti contoh berikut.

$$
\mathrm{ETD}_{\mathrm{k}}=T E k / D k
$$

Dari hasil perhitungan akan diambil 3 aksi mitigasi dengan ratio terbesar. Tabel 9 menunjukkan perhitungan HOD2 \& ranking (peringkat) aksi mitigasi yang harus diprioritaskan.

Berdasarkan tabel peringkat aksi mitigasi di atas diambil tiga peringkat teratas dalam aksi mitigasi sebagai berikut.

1. Melakukan komunikasi dan koordinasi yang baik dengan owner (PA3), komunikasi dan koordinasi dengan owner diperbaiki, sehingga pekerjaan konstruksi bisa berjalan kembali dengan baik, kesalahpahaman dan human error dapat terminimalisasi.

2. Membuat prosedur pembuatan dan perubahan gambar (PA5), dikarenakan peringkat tertinggi pada agen keterlambatan adalah perubahan gambar yang berulang-ulang maka sangat diperlukan prosedur pembuatan dan perubahan gambar yang jelas agar perubahan

\begin{tabular}{|c|c|c|c|c|c|c|c|}
\hline & \multicolumn{6}{|c|}{ Preventive Action (PAK) } & \multirow[b]{2}{*}{$\begin{array}{c}\text { Aggregate } \\
\text { Delay } \\
\text { Potentials } \\
\text { (ADPj) }\end{array}$} \\
\hline To be treated delay agent $(\mathrm{Aj})$ & PA1 & PA2 & PA3 & PA4 & PA5 & PA6 & \\
\hline A12 & 3 & 3 & 3 & 1 & 9 & 0 & 685 \\
\hline A5 & 3 & 3 & 9 & 3 & 9 & 9 & 595 \\
\hline $\mathrm{A} 3$ & 3 & 9 & 9 & 9 & 3 & 3 & 476 \\
\hline \multirow[t]{2}{*}{ Total effectiveness of action $\mathrm{k}$} & 5268 & 8124 & 11694 & 6754 & 12948 & 6783 & \\
\hline & PA1 & PA2 & PA3 & PA4 & PA5 & PA6 & \\
\hline $\begin{array}{l}\text { Degree of difficulty performing } \\
\text { action k }\end{array}$ & 3 & 3 & 3 & 4 & 4 & 3 & \\
\hline Effectiveness to difficulty ratio & 1756 & 2708 & 3898 & 1688,5 & 3237 & 2261 & \\
\hline Rank of priority & 5 & 3 & 1 & 6 & 2 & 4 & \\
\hline
\end{tabular}

Tabel 9 Perhitungan HOD2 dan Peringkat Aksi Mitigasi 


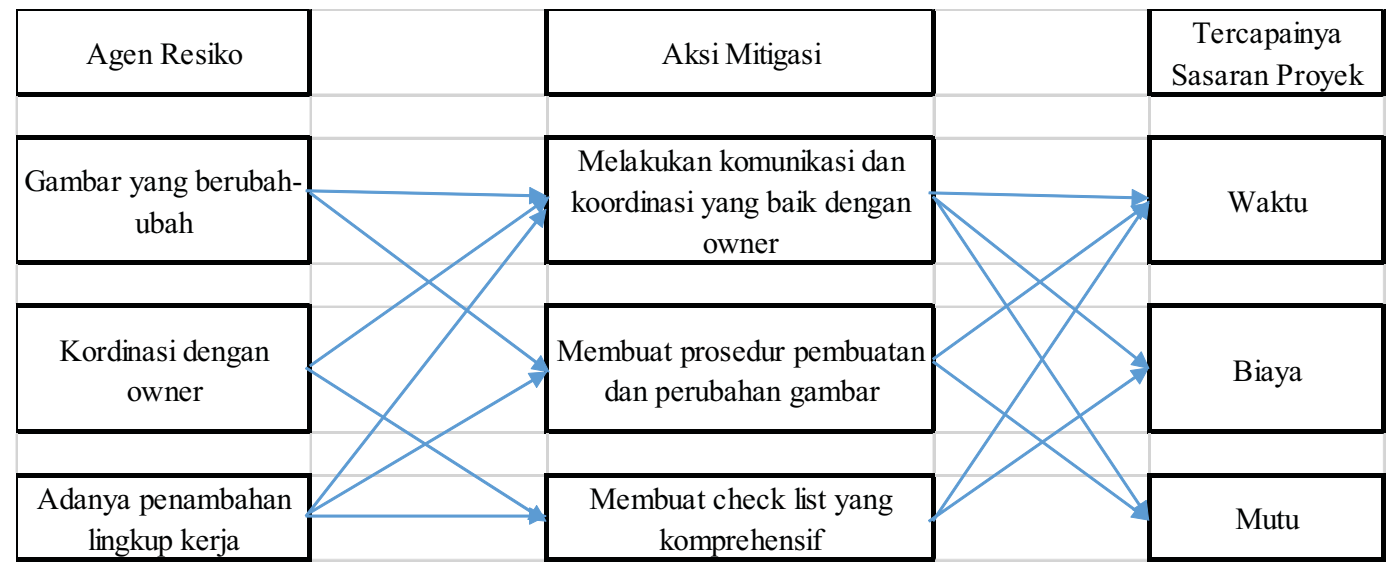

Gambar 5 Hasil HOD

gambar tersebut tidak menjalar keterlambatannya ke agent keterlambatan yang lain.

3. Membuat checklist yang komprehensif (PA2), hal ini bermaksud agar semua proses proyek yang ada dapat terpantau secara sistematis progresnya dan dapat diketahui maping area mana yang dikerjakan tiap-tiap kontraktor.

Untuk tercapainya sasaran proyek dapat diketahui aksi mitigasi dari masing-masing agen keterlambatan yang dapat dilihat pada Gambar 6 berikut.

1. Gambar yang berubah-ubah dapat diatasi dengan cara membuat prosedur pembuatan dan perubahan gambar yang jelas dan sistematis. Selain itu selama terjadi perubahan gambar melakukan komunikasi dan koordinasi yang baik dengan owner adalah hal yang sangat perlu. Melalui aksi mitigasi di atas diharapkan dapat tercapainya sasaran proyek dari sisi waktu, biaya, maupun mutu.

2. Koordinasi dengan owner merupakan hal yang paling sering menjadi agen masalah pada proyek yang akan maupun sedang berjalan. Dengan melakukan komunikasi dan koordinasi yang baik dengan owner maka hal tersebut dapat diatasi dengan baik. Selain itu, membuat checklist yang komprehensif akan sangat membantu saat melakukan koordinasi dengan owner.

3. Adanya penambahan lingkup kerja menjadi penyebab masalah yang cukup serius pada suatu proyek. Hal ini dapat diatasi dengan melakukan komunikasi dan koordinasi yang baik dengan owner. Dengan adanya penambahan lingkup kerja, besar kemungkinan terdapat perubahan pada gambar. Membuat prosedur pembuatan dan perubahan gambar adalah solusi yang tepat untuk mengatasi hal itu selain membuat checklist yang komprehensif tentang penambahan lingkup kerja itu sendiri.

\section{KESIMPULAN}

\section{Kesimpulan}

Dari penelitian yang sudah di lakukan, metode House of Risk dapat digunakan untuk menganalisis keterlambatan menjadi House of Delay dan mendapatkan hasil sebagai berikut.

1. Terdapat lima kejadian keterlambatan yang diidentifikasi penulis dalam proyek pembangunan Mall yaitu keterlambatan pembayaran oleh owner, keterlambatan material, keterlambatan pekerjaan akibat kesalahan kontraktor, keterlambatan akibat kesalahan owner, keter- 
lambatan serah terima pekerjaan kontraktor. Dan terdapat juga tiga belas agen/penyebab keterlambatan yang telah diidentifikasi yaitu terjadi tabrakan dalam lingkup kerja kontraktor, berkas pembayaran material yang tidak sesuai, penambahan lingkup kerja, proses pembayaran oleh owner, kurang koordinasi owner, perbedaan harga dasar, berkas kontraktor tidak lengkap dan sesuai, kurangnya sumber daya manusia pada kontraktor, sumber material berasal dari luar negeri, survei awal kontraktor tidak sesuai, perbedaan volume material, perubahan gambar, permintaan customer yang berbeda-beda.

2. Dari analisis data pada faktor keterlambatan tersebut maka dapat diperoleh hasil bahwa peringkat dari agen keterlambatan yang paling besar dan aksi mitigasi untuk masingmasing agen keterlambatan adalah sebagai berikut.

a. Gambar yang berubah-ubah dapat diatasi dengan cara membuat prosedur pembuatan dan perubahan gambar yang jelas dan sistematis. Selain itu, selama terjadi perubahan gambar melakukan komunikasi dan koordinasi yang baik dengan owner adalah hal yang sangat perlu. Melalui aksi mitigasi di atas diharapkan dapat tercapainya sasaran proyek dari sisi waktu, biaya, maupun mutu.

b. Koordinasi dengan owner merupakan hal yang paling sering menjadi agen masalah pada proyek yang akan maupun sedang berjalan. Dengan melakukan komunikasi dan koordinasi yang baik dengan owner maka hal tersebut dapat diatasi dengan baik. Selain itu, membuat checklist yang komprehensif akan sangat membantu saat melakukan koordinasi dengan owner. c. Adanya penambahan lingkup kerja menjadi penyebab masalah yang cukup serius pada suatu proyek. Hal ini dapat diatasi dengan melakukan komunikasi dan koordinasi yang baik dengan owner. Dengan adanya penambahan lingkup kerja, besar kemungkinan terdapat perubahan pada gambar. Membuat prosedur pembuatan dan perubahan gambar adalah solusi yang tepat untuk mengatasi hal itu selain membuat checklist yang komprehensif tentang penambahan lingkup kerja itu sendiri.

\section{DAFTAR PUSTAKA}

A.D., Austen dan R.H., Neale. 1991. Manajemen Proyek Konstruksi. Jakarta: PPM.

Ahyari, Agus. 1987. Manajemen Produksi Pengendalian Produksi. Yogyakarta: BPFE.

Assaf, S.A. and Al-Hejji S. 2006. Causes of Delay in Large Construction Projects. International Journal of Project Management, 24(4), 349-57.

Association of Project Managers. 2006. APM Body of Knowledge, 5ed. London: PPM. Billinton, R., dan Allan R.N. 1992. Reliability Evaluation of Engineering System Concepts and Techniques, Edisi 2. New York dan London: Plenum Prees.

Brown, D.B. 1976. System Analysis o Design for Safety. Englewood Cliffs: Prentice-Hall.

Callahan, M.T. 1992. Construction Project Scheduling. New York: McGraw-Hill.

Dipohusodo. 1996. Manajemen Proyek dan Konstruksi, Jilid 1 dan 2. Yogyakarta: Kanisius.

Donald S. Barrie, Boyd C. Paulson. 1984. Manajemen Konstruksi Profesional. Terj. Sudinarto. Jakarta: Erlangga. 
Ramdhan Yundra Saputra \& Imam Baihaqi, Penggunaan Metode House of Risk untuk Analisis Faktor Keterlambatan dan Penyusutan Strategi Penanganan: Studi Kasus Pembangunan Mall

Hervanda, Yosi. 2013. Analisis Keterlambatan

Proyek Konstruksi Jalan yang Disebabkan Faktor Material di Kabupaten Rokan Hulu. Tugas Akhir S-1 Teknik Sipil, Universitas Pasir Pengaraian.

Jervis, B.M. \& Levin, P. 1988. Construction Law. McGraw-Hill, Inc.

Kamaruzzaman, F. 2012. Studi Keterlambatan Penyelesaian Proyek Konstruksi. Jurnal Teknik Sipil Untan, Volume 12, Nomor 2, Desember 2012.

Kocecioglu, D. 1991. Reliability Engineering Handbook. Englewood Cliffs: PrenticeHall, Volume 2.

Kurniawan. 2015. Studi Keterlambatan Proyek Pembangunan Kapal Kargo dengan Metode Bow Tie Analysis. Tugas Akhir S1Teknik Kelautan, Institut Teknologi Sepuluh Nopember, Surabaya.

Levis and Atherley. 1996. Delay Construction. Langford: Cahner Books Internasional.

O‘Brien J.J. 1976. Managing Method and Management. The Dryden Press.

Popescu, C.M. dan Charoengam, C. 1995, Project Planning, Scheduling, and Control in Construction, p.188. Canada: John Willey \& Son.

Pramulia, R.D. \& Adi, T.J. 2015. Analisis Penyebab Keterlambatan Proyek Pabrik Es dengan Metode Fault Tree Analysis (Studi Kasus Perusahaan Daerah Aneka Usaha
Kabupaten Trenggalek Periode 20082012). Seminar Nasional Manajemen Teknologi III.

Pujawan, I.N. dan Geraldin, L.H. 2009. "House of Delay: a Model for Proactive Supply Chain Delay Management". Business Process Management Journal, Vol. 15.

Putra, A.T. 2014. Evaluasi Keterlambatan pada Proyek Pembangunan Jacket Structure: Studi Kasus Proyek EPCC Bukit Tua PT PAL Indonesia. Tugas Akhir S1-Teknik Kelautan, Institut Teknologi Sepuluh Nopember Surabaya.

Rosdianto, M.A. 2014. Analisis Percepatan Durasi Pengerjaan Proyek Pembangunan Jacket Platform di PT Meindo Elang Indah. Tugas Akhir S1-Teknik Kelautan, Institut Teknologi Sepuluh Nopember, Surabaya.

Rosyid, D.M. 2007. Pengantar Rekayasa Keandalan. Surabaya: Airlangga University Press.

Scott and Sttephen. 1997. "Delay Claims in UK Contracts". Journal of Construction Engineering and Management, Sept 1997, p. 238.

Soekoto, Imam. 1993. Pengendalian Pelaksanaan Konstruksi. Jakarta: Badan Penerbit Pekerjaan Umum.

Wulfram I. Ervianto. 2005. Manajemen Proyek Konstruksi. Yogyakarta: Andi Offset. 
Accounting and Management Journal, Vol. 1, No. 2, December 2017 